\title{
Factors structuring the spatial distribution of Chironomidae larvae community in the floodplain of the Northern Pantanal, Brazil
}

\author{
Fatores estruturadores da distribuição espacial da comunidade de larvas de \\ Chironomidae na planície de inundação do Pantanal norte, Brasil
}

Maitê Tambelini dos Santos ${ }^{1}$, Claudia Tasso Callil ${ }^{2}$, Ibraim Fantin-Cruz ${ }^{3}$ and Pierre Girard ${ }^{4}$

'Programa de Pós-graduaçáo em Ecologia e Conservação da Biodiversidade,

Instituto de Biociências, Universidade Federal de Mato Grosso - UFMT,

Av. Fernando Corrêa da Costa, s/n, Coxipó, CEP 78060-900, Cuiabá, MT, Brazil

e-mail: maitecbio@ahoo.com.br

${ }^{2}$ Departamento de Biologia e Zoologia, Instituto de Biociências,

Universidade Federal de Mato Grosso - UFMT, Av. Fernando Corrêa da Costa, s/n, Coxipó,

CEP 78060-900, Cuiabá, MT, Brazil

e-mail: callil@ufmt.br

${ }^{3}$ Instituto de Pesquisas Hidráulicas, Universidade Federal do Rio Grande do Sul - UFRGS, Av. Bento Gonçalves, 9500, CEP 91501-970, Porto Alegre, RS, Brazil

e-mail: ibraimfantin@gmail.com

${ }^{4}$ Departamento de Botânica e Ecologia, Instituto de Biociências,

Universidade Federal de Mato Grosso - UFMT, Av. Fernando Corrêa da Costa, s/n, Coxipó, CEP 78060-900, Cuiabá, MT, Brazil

e-mail: pierregirad1301@gmail.com

\begin{abstract}
Aim: In order to identify the factors structuring the spatial distribution of the Chironomidae community, we analyzed the effects of water and sediment characteristics, flood duration and type of phytophysiognomic unit on the taxa composition of this community. Métodos: O estudo foi realizado em 26 parcelas do Sítio de Amostragem de Longa Duração (SALD), localizado em uma área sazonalmente inundável na parte norte do Pantanal (Brasil). The study was conducted at 26 plots of the Long-Term Sampling Site, located in a seasonally flooded area in northern Pantanal (Brazil). Sediment samples were taken from each plot to analyze the Chironomidae community, organic matter and particle size; limnological parameters (depth, water temperature, dissolved oxygen, electrical conductivity and $\mathrm{pH}$ ); besides the duration of flood. Results: We identified 432 individuals distributed into 21 Chironomidae taxa. Polypedilum and Ablabesmyia were the most frequent spatially. The multivariate multiple regression analysis showed that the community composition was significantly related to the flood duration and grain size characteristics, but not to phytophysiognomic units and limnological parameters. Plots with predominantly sandy substrate and flooded for a shorter time presented a greater occurrence of taxa. Conclusions: The gradient produced by the spatial distribution of sediment grain size and flood duration determined the distribution of Chironomidae taxa. Changes in the hydrological functioning of the Pantanal, such as those from reservoir construction in the uplands region and roads and dykes construction in the floodplain could then impact the local chironomid biodiversity.
\end{abstract}

Keywords: flood duration, sediment grain size, composition of community, chironomids, Pantanal.

Resumo: Objetivos: Para identificar os fatores estruturadores da distribuição espacial da comunidade de Chironomidae, analisamos os efeitos das características da água e do sedimento, da duração da inundação e do tipo de unidade fitofisionômica sobre composição de táxons desta comunidade. Métodos: $\mathrm{O}$ estudo foi realizado em 26 parcelas do Sítio de Amostragem de Longa Duração (SALD), localizado em uma área sazonalmente inundável na parte norte do Pantanal (Brasil). Em cada parcela foram coletadas amostras de sedimento para analisar a comunidade de Chironomidae, matéria orgânica e granulometria; parâmetros limnológicos (profundidade, temperatura da água, oxigênio dissolvido, condutividade elétrica e $\mathrm{pH}$ ); além da duração da inundação. Resultados: Foram encontrados 432 indivíduos, distribuídos em 21 taxa de Chironomidae. Os táxons Polypedilum e Ablabesmyia foram os mais frequentes espacialmente. A análise de regressão múltipla multivariada mostrou que a composição 
da comunidade de Chironomidae foi significativamente relacionada com a duraçáo da inundação e características granulométricas, mas não com as unidades fitofisionômicas e os parâmetros limnológicos. As parcelas com substrato predominantemente arenoso e inundadas por um menor período de tempo apresentaram maior ocorrência de táxons. Conclusóes: $\mathrm{O}$ gradiente espacial gerado pela distribuição espacial da granulometria do sedimento e duração da inundação determinaram a distribuição dos táxons de quironomídeos. Assim, alteraçóes no funcionamento hidrológico do Pantanal, como os da construçâo de reservatórios na regiáo do Planalto e estradas e diques na planicie de inundação poderia afetar a biodiversidade local de quironomídeos.

Palavras-chave: duração da inundação, granulometria do sedimento, composição da comunidade, quironomídeos, Pantanal.

\section{Introduction}

The seasonal hydrological variation is an important component for the maintenance of the ecological functioning of floodplain ecosystems and also controls the structure of biological communities (Junk et al., 1989; Tockner et al., 1999; Junk et al., 2006).

In floodplains, larvae of the family Chironomidae can be the most abundant invertebrate group (Sommer et al., 2004; Benigno and Sommer, 2008). The Chironomidae community usually changes in response to physical and chemical variations of the water (Higuti and Takeda 2002). The geomorphological, hydraulic and limnological variations, as well as the size of particles comprising the sediment, are some of the factors that influence the temporal and spatial distribution of this community (Stevaux and Takeda 2002; Ali et al., 2002; Marchese et al., 2005).

Studies on the Chironomidae community structure in the Pantanal are restricted to permanent water bodies (Ezcurra de Drago et al., 2004; Marchese et al., 2005; Aburaya and Callil, 2007). All these studies described the relationship between this community and environmental variables, such as the type of sediment and physicochemical parameters of the water; however the effect of the flood duration in the floodplain had not been investigated.

Nevertheless, in seasonally flooded environments there is no information whether these relationships are kept, since the same area annually presents aquatic phase and terrestrial phases. In studies with other groups, in environments with this same dynamics, the flood duration (hydroperiod) is the determining factor for the spatial distribution of species (Fantin-Cruz et al., 2008; Fernandes et al., 2010; Pagotto et al., 2011; Tondato et al., 2013).

Another aspect to be analyzed in this study is the relationship between the phytophysiognomic unit and the Chironomidae community structure. Flood duration is the determinant ecological factor for the distribution of plant species (Rebellato and Cunha 2005; Fantin-Cruz et al., 2010). However, the vegetation in great part of the Pantanal has been altered for the livestock production (Junk and Cunha, 2012). As well, high levels of deforestation and the replacement of native vegetation for exotic species have impacts on the aquatic invertebrate community (Steinman et al., 2003). Such information is crucial for identifying priority areas with the purpose of conservation and definition of management strategies.

Given the need to understand what factors influence the spatial distribution of Chironomidae community in the seasonally flooded area of the northern Pantanal, the objective of this research was to characterize the Chironomidae taxa in terms of occurrence, and to respond the following questions: the relative frequency of taxa vary spatially with: (i) the characteristics of the water, sediment and flood duration? (ii) with the different types of phytophysiognomic units?

\section{Material and Methods}

\subsection{Study area}

The regional climate is Köppen's AW type, hot with humid summer and dry winter. The mean annual precipitation in the Pantanal varies from 1100 to $1200 \mathrm{~mm}$, concentrated in December, January and February, and the mean annual temperature varies between 17 and $32{ }^{\circ} \mathrm{C}$ (Alvarenga et al., 1984). Soils have sedimentary origin, occurring in alternating and discontinuous clay and sandy layers with predominance of hydromorphic soils covering up to $92.5 \%$ of the total area (Amaral Filho, 1984)

This study was conducted on the Long-Term Sampling Site (LTSS) located in the county of 
Nossa Senhora do Livramento, Mato Grosso State, locally known as Pantanal of Poconé (Figure 1). It is a seasonally flooded area, showing a low inundation size $($ mean $=24 \mathrm{~cm})$ and medium duration $($ mean $=85$ days). This area is included in the Cuiabá River basin, and the flood results from incoming waters from the Cuiabá River and regional rainfall runoff (Fantin-Cruz et al., 2010).

The vegetation of the region consists in four phytophysiognomic units: "campo inundável" (flooded grassland); "cordilheira" (dense arboreal savanna); "landizal" (seasonally flooded evergreen forest) and "Cambarazal" (monodominant Vochysia divergens Pohl. forest) (Fantin-Cruz et al., 2010).

\subsection{Sampling design}

The Long-Term Sampling Site (LTSS) is a grid formed by a system of six lines, $5 \mathrm{~km}$ long tracks covering a total area of $25 \mathrm{~km}^{2}$. A sampling plot was established every $1 \mathrm{~km}$ on the tracks in the east-west direction. The $250 \mathrm{~m}$ long sampling plots were demarcated in order to follow the contour in linear sections 10 to $10 \mathrm{~m}$. The 30 sampling plots have no definite shape, for each sampling plot is the same corner of the field level and aim to minimize the variation of topography within each plot (Signor and Pinho, 2011).

Samples were collected in February 2007, during the overflow period, considering the flooded plots (26). In each plot we collected three sediment samples (50 $\mathrm{m}$ away) using a Petersen grab to examine the Chironomidae community, organic matter and particle size.

For the analysis of the Chironomidae community, the biological material was washed in a set of four sieves $(2.0,1.0,0.25$, and $0.125 \mathrm{~mm}$ mesh size). Chironomidae larvae were mounted on slides with Hoyer medium for later identification to genus level using the identification key of TrivinhoStrixino (2011).

For the analysis of organic matter, each sample was divided into three sub-samples, for replication. The percentage of organic matter in the sediment was obtained by the difference between the dry weight and the weight of the material calcined in a muffle furnace.

A sample composed of sediments was used for the particle size analysis. The sediment of the three samples from each plot was mixed and a 1000 g-portion was separated. This material was placed in a set of sieves and characterized as: silt + clay $=$ sediments retained on the $0.063 \mathrm{~mm}$ mesh; fine sand = sediments retained on the $0.125 \mathrm{~mm}$ mesh; and medium sand = sediments retained on the $0.250 \mathrm{~mm}$ mesh.

For water characterization, at each sampling site we measured the $\mathrm{pH}$, temperature, electrical conductivity and dissolved oxygen using a portable multiparameter probe YSI, the water column depth was measured using a ruler.

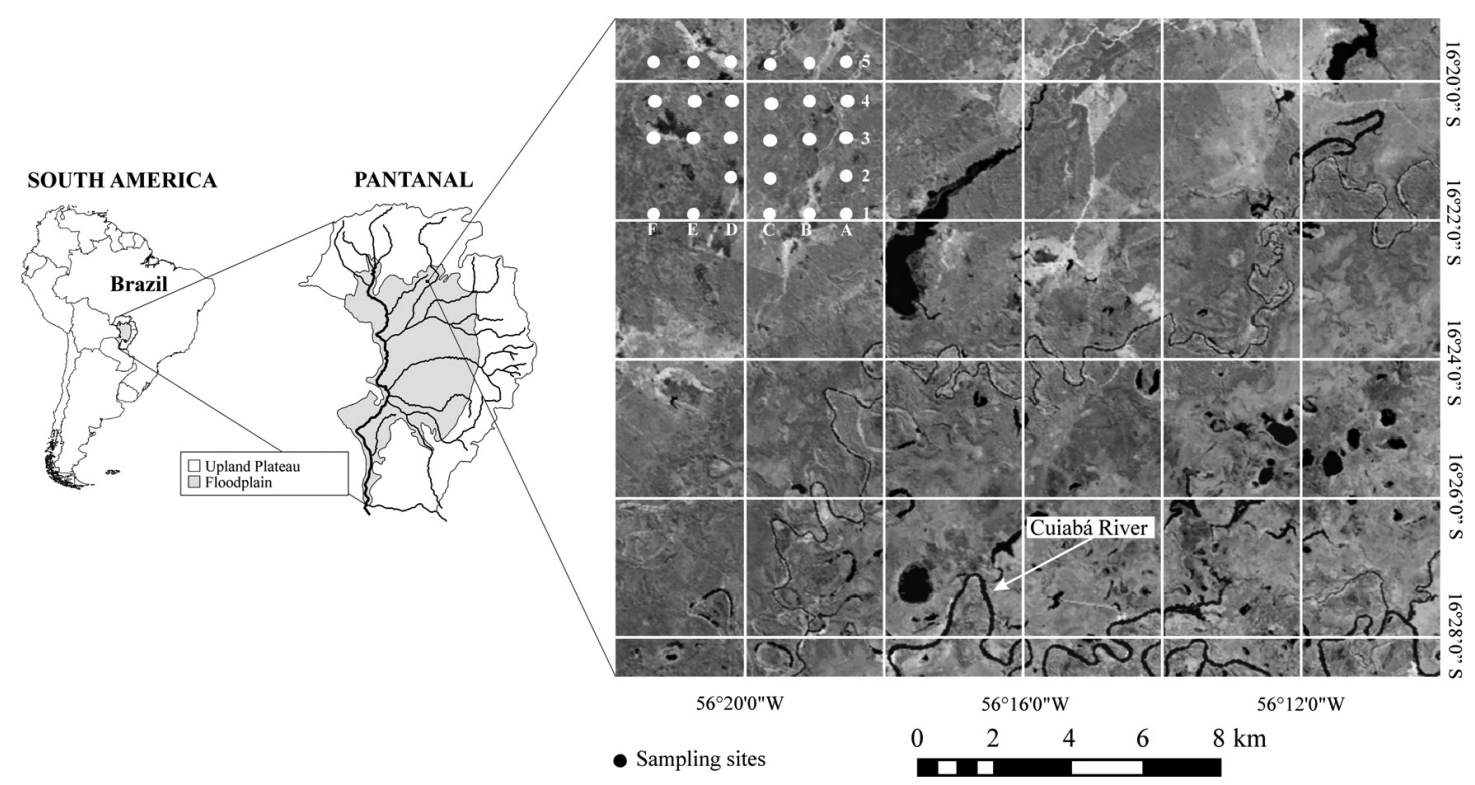

Figure 1. Location of the study area and of the Long-Term Sampling Site (LTSS) in a seasonally flooded area of the northern Pantanal, Brazil. 
We used data of the flood duration during the overflow period between 2006 and 2007 (FantinCruz et al., 2010), where the flood duration is the time in days at which the floodplain remained flooded.

The vegetation was categorized into three types: fields with native pasture, fields with exotic pasture and arboreal vegetation. This classification was based on the three main types of management used for extensive livestock farming in this region of the Pantanal.

\subsection{Data analysis}

Prior to statistical analysis, values of water and sediment parameters were transformed and normalized to meet the assumptions of homoscedasticity and normality (Gotelli and Ellison, 2011). The taxonomic composition of Chironomidae larvae was presented in terms of presence and absence.

In order to ordinate plots in relation to water parameters and sediment characteristics, we used a principal component analysis (PCA) with the program SYSTAT 10. We reduce the dimensionality of the data of the Chironomidae larvae composition using a non-metric multidimensional scaling (NMDS), with the software PC-ORD 5.0. Sampling plots were ranked in order of relative frequency occurrence of taxa using the Bray-Curtis distance for the standardized occurrence data. We separated the three axes generated, since they were considered the strongest pattern in the community, to be used in subsequent analyses.

We tested the correlations between taxa composition (three axes of NMDS) and environmental variables (water and sediment parameters and flood period) using a multivariate multiple regression with SYSTAT 10. Explanatory variables shown to be significantly related to taxa composition were used to create direct ordination diagrams, which demonstrated the spatial variation in the Chironomidae larvae community in the seasonally flooded area, in terms of environmental gradient.

A multivariate analysis of covariance (MANCOVA) was employed to evaluate the effect of the phytophysiognomic units on the occurrence of Chironomidae taxa. For this analysis, it was used the community composition in the plots (first axis of NMDS) as the response variable; the variables with significant effects on the composition as covariates; and phytophysiognomic units as the categorical variable.

\section{Results}

\subsection{Chironomidae community composition}

We collected a total of 432 Chironomidae individuals belonging to three subfamilies: Ortocladiinae, Tanypodinae and Chironominae. The tribe Chironomini (Chironominae) was the most representative with 8 genera and $61.3 \%$ of the total number of individuals (Table 1). It was followed by Pentaneurini (Tanypodinae), Tanytarsini (Chironominae), Procladiini (Tanypodinae), Coelotanypodini (Tanypodinae) and Corynoneurini (Ortocladiinae).

The most common taxa were Polypedilum and Ablabesmyia, occurring in $77.8 \%$ and $70.4 \%$ of plots, respectively. In turn, Phaenopsectra, Goeldichironomus, Stenochironomus, Zavreliella, Tanytarsus obiriciae Trivinho-Strixino \& Sonoda, 2006, Tanytarsus, Larsia, Djalmabatista pulchra

Table 1. Percentage of occurrence and relative abundance of 21 Chironomidae genera in 26 plots in February 2007 at the Long-Term Sampling Site (LTSS), Pantanal, Brazil.

\begin{tabular}{|c|c|c|}
\hline Taxa & $\begin{array}{c}\text { Occurrence } \\
(\%)\end{array}$ & $\begin{array}{c}\text { Relative } \\
\text { abundance } \\
(\%)\end{array}$ \\
\hline \multicolumn{3}{|l|}{ Subfamily Chironominae } \\
\hline \multicolumn{3}{|l|}{ Tribe Chironomini } \\
\hline Beardius & 37.0 & 8.1 \\
\hline Chironomus & 18.5 & 1.4 \\
\hline Cryptochironomus & 7.4 & 0.5 \\
\hline Dicrotendipes & 25.9 & 7.2 \\
\hline Goeldichironomus & 3.7 & 0.2 \\
\hline Harnischia & 7.4 & 0.5 \\
\hline Parachironomus & 22.2 & 2.8 \\
\hline Phaenopsectra & 3.7 & 0.5 \\
\hline Polypedilum & 77.8 & 39.8 \\
\hline Stenochironomus & 3.7 & 0.2 \\
\hline Zavreliella & 3.7 & 0.2 \\
\hline \multicolumn{3}{|l|}{ Tribe Tanytarsini } \\
\hline Caladomyia & 37.0 & 5.8 \\
\hline Tanytarsus obiriciae & 3.7 & 0.2 \\
\hline Tanytarsus & 3.7 & 0.2 \\
\hline \multicolumn{3}{|l|}{ Subfamily Tanypodinae } \\
\hline \multicolumn{3}{|l|}{ Tribe Coelotanypodini } \\
\hline Coelotanypus & 29.6 & 3.9 \\
\hline \multicolumn{3}{|l|}{ Tribe Pentaneurini } \\
\hline Ablabesmyia & 70.4 & 19.4 \\
\hline Labrundinia & 29.6 & 3.5 \\
\hline Larsia & 3.7 & 0.2 \\
\hline \multicolumn{3}{|l|}{ Tribe Procladiini } \\
\hline Procladius & 40.7 & 4.9 \\
\hline Djalmabatista pulchra & 3.7 & 0.2 \\
\hline \multicolumn{3}{|l|}{ Subfamily Orthocladiinae } \\
\hline \multicolumn{3}{|l|}{ Tribe Corynoneurini } \\
\hline Corynoneura & 3.7 & 0.2 \\
\hline
\end{tabular}


Karunakaran, 1969 and Corynoneura occurred in only one plot, and thus were considered rare.

\subsection{Relationship between Chironomidae community and environmental variables}

Of the 26 flooded plots, seven were located in an arboreal area, 15 in fields with native vegetation and four in fields with exotic pasture. The water column had low depth $(>53 \mathrm{~cm})$, slightly acid $\mathrm{pH}(>7)$, and lower concentrations of dissolved oxygen (mean $\left.4.9 \mathrm{mg} \cdot \mathrm{L}^{-1}\right)$. Electrical conductivity varied slightly between plots $\left(7-36 \mu \mathrm{S} . \mathrm{cm}^{-1}\right)$. Flood duration ranged from six to 200 days. The high variability of the water temperature was because measurements were taken at different times of the day. Particle size of sediment and organic matter percentage, as well as the values of the environmental variables are listed in Table 2.

The PCA summarized the environmental variables into two axes for both limnological $(82.9 \%)$ and sediment variables $(95.9 \%)$. The first PCA axis for limnological variables was explained by $\mathrm{pH}(0.937)$, dissolved oxygen (0.87) and depth $(-0.79)$, whereas the second axis was explained by conductivity $(-0.94)$. For sediment variables, the first PCA axis was explained by clay/silt $(0.95)$ and by medium $(-0.98)$ and fine sand $(0.88)$, and the second axis was explained by organic matter $(0.75)$.

After ordination using NMDS, the dimensionality of the data regarding the occurrence of Chironomidae larvae was summarized into three axes. All NMDS axes captured great part of the distance variation among plots for quantitative data $(68.2 \%)$.

The multiple regression analysis showed that the abundance of the Chironomidae community,

Table 2. Environmental variables measured in 26 plots in February 2007 at the Long-Term Sampling Site (LTSS), Pantanal, Brazil.

\begin{tabular}{lcc}
\hline \multicolumn{1}{c}{ Variables } & $\begin{array}{c}\text { Mean } \\
(\text { SD) }\end{array}$ & $\begin{array}{c}\text { Minimal- } \\
\text { Maximal }\end{array}$ \\
\hline Depth $(\mathrm{cm})$ & $26.5(13.0)$ & $7.3-52.7$ \\
Temperature $\left({ }^{\circ} \mathrm{C}\right)$ & $30.0(2.8)$ & $26.8-36.2$ \\
$\mathrm{DO}\left(\mathrm{mg}^{-} \mathrm{L}^{-1}\right)$ & $4.9(2.1)$ & $1.6-8.7$ \\
Conductivity & $13.7(5.7)$ & $7.3-36.3$ \\
$\mathrm{pH}$ & $5.9(0.5)$ & $4.9-6.9$ \\
Organic matter $(\%)$ & $1.6(1.8)$ & $0.57-9.79$ \\
Silt-clay $(\%)$ & $12.6(6.1)$ & $3.6-31.2$ \\
Fine sand $(\%)$ & $12.2(4.4)$ & $4.7-21.4$ \\
Medium sand (\%) & $75.1(9.8)$ & $52.4-91.6$ \\
Flood duration (days) & $100.3(42.2)$ & $6-200$ \\
\hline
\end{tabular}

represented by all three NMDS axes, was significantly related to the first PCA axis for sediment (Pillai Trace: $\mathrm{F}_{3,20}=3.26, \mathrm{p}=0.04$ ) and to the flood duration (Pillai Trace: $\mathrm{F}_{3,20}=4.2, \mathrm{p}=0.02$ ), but there was no significant evidence of relationship with the first PCA axis for water parameters (Pillai Trace: $\left.\mathrm{F}_{3,20}=0.67, \mathrm{p}=0.58\right)$

To illustrate the effect of flood duration and sediment variables on the Chironomidae community, we performed a direct ordination between the abundance of each genus in the plots and the significantly related variables. Polypedilum and Labrundinia occurred throughout the gradient of flood duration. Differently from the Corynoneura that was restricted to plots with shorter flood duration (Figure 2).

Polypedilum, Labrundinia and Beardius also occurred in the plots regardless of the type of particles in the sediment. Most genera have been concentrated to the right side of PCA 1 for sediment, which was mainly influenced by medium sand (Figure 3).

The flood duration and sediment had a significant relationship with Chironomidae composition, and thus were considered covariates in the evaluation of the effect of vegetation. The MANCOVA analysis indicated that the Chironomidae composition in the study area was not affected by the phytophysiognomic units (MANCOVA: Pillai Trace $=0.27, \mathrm{~F}_{6,42}=1.11$, $\mathrm{p}=0.37)$.

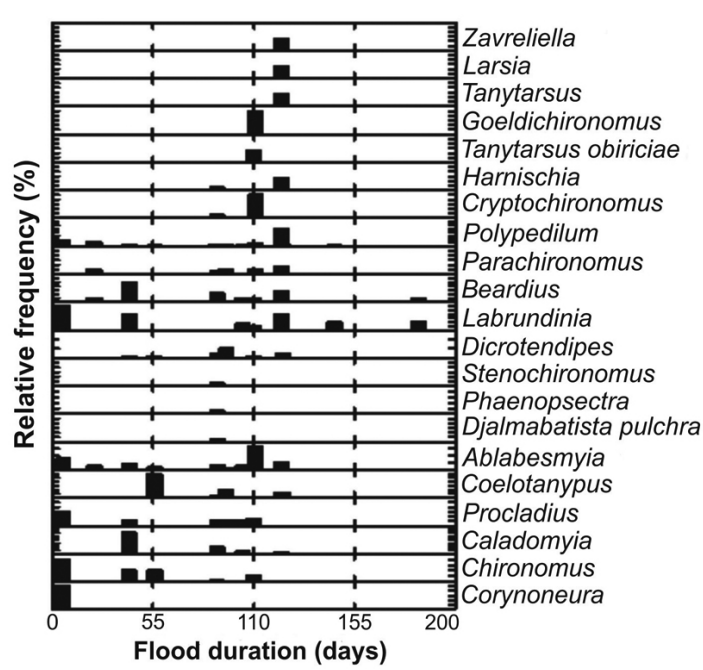

Figure 2. Relative frequency of Chironomidae genera along the gradient in flood duration in a seasonally flooded area of the northern Pantanal, Brazil. 


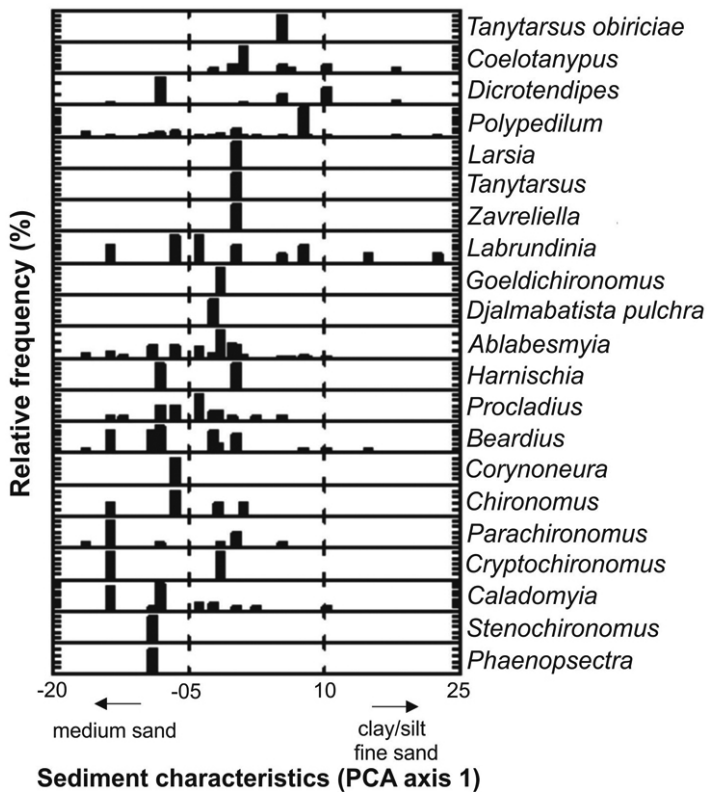

Figura 3. Relative frequency of Chironomidae genera along the gradient in sediment characteristics (PCA axis 1) in a seasonally flooded area of the northern Pantanal, Brazil.

\section{Discussion}

Flood duration and sediment were the variables that ruled the distribution of the Chironomidae community. The sediment composition determined their abundance and distribution, similarly to most benthic macroinvertebrates (Ali et al., 2002; Marchese et al., 2005; Resende and Takeda, 2007). A sandy substrate generally presents lower diversity compared with other substrates (Ali et al., 2002). However, most taxa found in this work have been concentrated in sites with predominance of sandy substrate.

Chironomidae taxa have occurred predominantly in sites that remained flooded for up to 130 days, very close to the average duration of the flood in the Pantanal, which is 120 days (Fantin-Cruz et al., 2011). This fact shows that these organisms have excellent colonizing abilities, rapid larval development (Wiggins et al., 1980; Higgins and Merritt, 1999; Sommer et al., 2004) and are adapted to the hydrological variability of this ecosystem. Besides, many Chironomidae species are resistant to desiccation and emerge from the sediment after few days of flooding (Benigno and Sommer, 2008; Tronstad et al., 2005).

Chironomidae larvae may be capable of tolerating daily or yearly fluctuations in the water level (Tronstad et al., 2005). Some studies carried out in this same floodplain reported that the flooding duration is the most important factor responsible for the distribution of different species of fauna and flora (Fantin-Cruz et al., 2010; Fernandes et al., 2010; Pagotto et al., 2011; Tondato et al., 2013).

In this study, the genus Polypedilum occurred in $77.8 \%$ of the sampled plots, and its highest abundance was found in sites with predominance of larger sediment particles and in sites under shorter flood period. Amorim et al. (2004) observed the presence of this genus in sandy substrates, being Polypedilum (Asheum) exclusively found in this type of substrate. Higuti and Takeda (2002) reported the dominance of Polypedilum in periods of low waters, indicating a preference for shallow areas. The presence of Polypedilum in almost all sites suggested that this genus includes species tolerant to a wide array of environmental conditions (Sanseverino and Nessimian, 1998).

The genus Ablabesmyia had preference for to plots with sandy sediment that remained flooded for a shorter time. This genus can feed on detritus or animals (Chironomidae larvae and microcrustacean) and has low selectivity, considered generalist (Henriques-Oliveira et al., 2003; Panatta et al., 2006).

Although Labrundinia has presented a lower occurrence frequency and relative abundance compared with Polypedilum and Ablabesmyia, it had wider distribution and occurred in plots regardless of flooding time and sediment particle size. The genus Procladius was present in plots with sandy substrate that remained flooded for a few days. This pattern was different from that found by Strixino and Trivinho-Strixino (1998) and Higuti and Takeda (2002), who reported the predominance of this genus in environments where the sediment consisted mainly of fine sand with a mud layer.

Taxa with restricted distribution are usually found in lentic environments (Goeldichironomus, Tanytarsus obiriciae, Tanytarsus), lotic environments (Zavreliella and Corynoneura) or both (Larsia and Djalmabatista pulcra) (Trivinho-Strixino, 2011). However given the hydrological functioning of the study area, where the seasonal cycle of flood and drought characterizes a temporary environment, we suggest that the colonization of these taxa was not favored by the stress generated by this environment.

In the presentstudy, the Chironomidaecommunity was not affected by the phytophysiognomic units, showing that this group does not reflect regional changes in habitat characteristics. This characteristic can be related to the greater phenotypic plasticity of the Chironomidae in relation to other aquatic 
insects, which gives them ecological and biological adaptations that enable them to explore different habitats (Trivinho-Strixino and Strixino, 2005). For benthic organisms, studies have already shown that local characteristics are more important than regional ones to the spatial structure of this group (Lammert and Allan, 1999).

In summary, the spatial distribution of chironomid composition was mainly related to the particle size and flood duration. In turn, it is widely known that the spatial distribution of sediment grain size as well as the flood duration in seasonal floodplain is linked to the hydrological regime and the degree of hydrological connectivity (Junk and Cunha, 2005). Among the factors that can affect regime and connectivity in floodplains, stand out the construction of dams in the uplands surrounding the Pantanal, and roads and dykes construction in the floodplain are the most commonly listed (Wantzen et al., 2008). These factors are ultimately relevant for the environmental management of the floodplain. Contrary to expected, types of vegetation do not seem to affect the spatial distribution of chironomids and, as such, invasion of stands of 'Cambarazal' (monodominant forest of Vochysia divergens Pohl.) and pasture formation, are not seen as preponderant factors that could influence chironomid diversity.

\section{Acknowledgments}

We thank to Cristina Márcia de Menezes Butakka for the help in the identification of Chironomidae larvae; Vera Uhde for helping with field work and material selection; Graduation Program in Ecology and Biodiversity Conservation at Federal University of Mato Grosso, Pantanal Research Center - CPP, Minister of Science and Technology - MCTI, and Biodiversity Research Program - PPBio, for financial and logistic support; and FAPEMAT for the scholarship, which is indispensable for the dedication to the Master's course.

\section{References}

ABURAYA, FH. and CALLIL, CT. 2007. Variação temporal de larvas de Chironomidae (Diptera) no alto Rio Paraguai, Cáceres, Mato Grosso, Brasil. Revista Brasileira de Zoologia, vol. 24, no. 3, p. 565-572. http://dx.doi.org/10.1590/S010181752007000300007

ALI, A., FROUZ, J. and LOBINSKE, RJ. 2002. Spatio-temporal effects of selected physico-chemical variables of water, algae and sediment chemistry on the larval community of nuisance Chironomidae (Diptera) in a natural and a man-made lake in central
Florida. Hydrobiologia, vol. 470, no. 1-3, p. 181-193. http://dx.doi.org/10.1023/A:1015696615939\%T

ALVARENGA, SM., BRASIL, AE., PINHEIRO, R. and HUX, HJH. 1984. Estudo geomorfológico aplicado à Bacia do alto Rio Paraguai e Pantanais Matogrossenses. Boletim Técnico Projeto RANDAM BRASIL. Série Geomorfologia, vol. 187, p. 89-183.

AMARAL FILHO, ZP. 1984. Solos do Pantanal MatoGrossense. In Anais do X Simpósio sobre recursos naturais e socioeconômicos do Pantanal, 1984. EMBRAPA-CPAP-UFMS. p. 265.

AMORIM, RM., HENRIQUES-OLIVEIRA, AL. and NESSIMIAM, JL. 2004. Distribuição espacial e temporal das larvas de Chironomidae (Insecta: Diptera) na seçáo ritral do rio Cascatinha, Nova Friburgo, Rio de Janeiro, Brasil. Lundiana, vol. 5, no. 2, p. 119-127.

BENIGNO, GM. and SOMMER, TR. 2008. Just add water: sources of chironomid drift in a large river floodplain. Hydrobiologia, vol. 600, p. 297-305. http://dx.doi.org/10.1007/s10750-007-9239-2

EZCURRA DE DRAGO, I., MARCHESE, M. and WANTZEN, KM. 2004. Benthos of a large neotropical river: spatial patterns and species assemblages in the Lower Paraguay and its floodplains. Archiv für Hydrobiologie, vol. 160, no. 3, p. 347-374. http://dx.doi.org/10.1127/0003-9136/2004/01600347

FANTIN-CRUZ, I., TONDATO, KK., PENHA, JMF., MATEUS, LAF., GIRARD, P. and FANTIN-CRUZ, R. 2008. Influence of fish abundance and macrophyte cover on microcrustacean density in temporary lagoons of the Northern Pantanal-Brazil. Acta Limnologica Brasiliensia, vol. 20, no. 4, p. 339-344.

FANTIN-CRUZ, I., GIRARD, P., ZEILHOFER, P., COLlisCHONN, W. and CUNHA, CN. 2010. Unidades fitofisionômicas em mesoescala no Pantanal Norte e suas relaçóes com a Geomorfologia. Biota Neotropica, vol. 10, no. 2, p. 31-38. http://dx.doi. org/10.1590/S1676-06032010000200002

FANTIN-CRUZ, I., PEDROLLO, O., CASTRO, NMR., GIRARD, P., ZEILHOFER, P. and HAMILTON, SK. 2011. Historical reconstruction of floodplain inundation in the Pantanal (Brazil) using neural networks. Journal of Hydrology, vol. 399, no. 3-4, p. 76-384. http://dx.doi.org/10.1016/j. jhydrol.2011.01.014

FERNANDES, IM., MACHADO, FA. and PENHA, J. 2010. Spatial pattern of fish assemblage in a seasonal tropical wetland: effects of habitat, herbaceous plant biomass, water depth and distance from species sources. Neotropical Ichtyology, vol. 8, no. 2, p. 289-298. http://dx.doi.org/10.1590/S167962252010000200007

GOTELLI, NJ. and ELLISON, AM. 2011. Princípios de estatística em ecologia. Porto Alegre: Artmed. 528 p. 
HENRIQUES-OLIVEIRA, AL., NESSIMIAN, JL. and DORVILLÉ, LFM. 2003. Feeding habitats of Chironomidae larvae (Insecta: Diptera) from a stream in the floresta da Tijuca, Rio de Janeiro, Brazil. Brazilian Journal Biology, vol. 63, p. 269-281. http:// dx.doi.org/10.1590/S1519-69842003000200012

HIGGINS, MJ. and MERRITT, RW. 1999. Temporary woodland ponds in Michigan: invertebrate seasonal patterns and trophic relationships. In BATZER, DP., RADER, RB. and WISSINGER, SA., eds. Invertebrates in Freshwater Wetlands of North America: Ecology and Management. New York: John Wiley \& Sons. p. 279-207.

HIGUTI, J. and TAKEDA, AM. 2002. Spatial and temporal variation in densities of chironomid larvae (Diptera) in two lagoons and two tributaries of the upper Paraná river floodplain, Brazil. Brazilian Journal Biology, vol. 62, no. 4B, p. 807-818. http:// dx.doi.org/10.1590/S1519-69842002000500010

JUNK, WJ., BAYLEY, PB. and SPARKS, RE. 1989. The flood pulse concept in river-floodplain systems. Canadian Special Publications of Fisheries Aquatic Sciences, vol. 106, p. 110-127.

JUNK, WJ. and CUNHA, NC. 2005. Pantanal: A large South American Wetland at a Crossroads. Ecological Engineering, vol. 24, no. 4, p. 391-401. http://dx.doi. org/10.1016/j.ecoleng.2004.11.012

JUNK, WJ. and CUNHA, CN. 2012. Pasture clearing from invasive Woody plants in the Pantanal: a tool for sustainable management or environmental destruction. Wetlands Ecology and Management, vol. 20, p. 111-122. http://dx.doi.org/10.1007/ s11273-011-9246-y.

JUNK, WJ., CUNHA, CN., WANTZEN, KM., PETERMANN, P., STRUSSMANN, C., MARQUES, MI. and ADIS, J. 2006. Biodiversity and its conservation in the Pantanal of Mato Grosso,Brazil. Aquatic Sciences, vol. 68, p. 278-309. http://dx.doi.org/10.1007/s00027-006-0851-4

LAMMERT, M. and ALLAN, JD. 1999. Assessing biotic integrity of streams: Effects of scale in measuring the influence of land use/cover on habitat structure on fish and macroinvertebrates. Environmental Management, vol. 23, no. 2, p. 257-270. http:// dx.doi.org/10.1007/s002679900184

MARCHESE, MR., WANTZEN, KM. and EZCURRA DE DRAGO, IE. 2005. Benthic invertebrates assemblages and species diversity patterns of the upper Paraguay River. River Research and Applications, vol. 21, no. 5, p. 485-499. http://dx.doi. org/10.1002/rra.814

PAGOTTO, MA., SILVEIRA, RML., CUNHA, CN. and FANTIN-CRUZ, I. 2011. Distribution of herbaceous species in the soil seed bank of a flood seasonality area, northern Pantanal, Brazil. International Review of Hydrobiology, vol. 96, p. 2, p. 149-163. http://dx.doi.org/10.1002/ iroh.201111315

PANATTA, A., STENERT, C., FREITAS, SMF. and MALTCHIK, L. 2006. Diversity of chironomid larvae in palustrine wetlands of the coastal plain in the south Brazil. Limnology, vol. 7, no. 1, p. 23-30. http://dx.doi.org/10.1007/s10201-005-0160-y

REBELLATO, L. and CUNHA, CN. 2005. Efeito do "fluxo sazonal mínimo da inundação" sobre a composição e estrutura de um campo inundável no Pantanal de Poconé, MT, Brasil. Acta Botânica Brasileira, vol. 19, no. 4, p. 789-799. http://dx.doi. org/10.1590/S0102-33062005000400015

RESENDE, DLMC. and TAKEDA, AK. 2007. Larvas de Chironomidae (Diptera) em três Reservatórios do Estado do Paraná, Brasil. Revista Brasileira de Zoociências, vol. 9, no. 2, p.167-176.

SANSEVERINO, AM., NESSIMIAN, JL. and OLIVEIRA, ALH. 1998. A fauna de Chironomidae (Diptera) em diferentes biótopos aquáticos na Serra do Subaio (Teresópolis, RJ). Oecologia BrasiliensesEcologia de insetos aquáticos, vol. 5, p. 253-263.

SIGNOR, CA. and PINHO, JB. 2011. Spatial diversity patterns of birds in a vegetation mosaico $f$ the Pantanal, Mato Grosso, Brasil. Zoologia, vol. 28, no. 6, p. 725-738. http://dx.doi.org/10.1590/S198446702011000600005

SOMMER, TR., HARRELL, WC., MUELLERSOLGER, A., TOM, B. and KIMMERER, W. 2004. Effects of flow variation on channel and floodplain biota and habitats of the Sacramento River, California, USA. Aquatic Conservation: Marine and Freshwater Ecosystems, vol. 14, no. 3, p. 247-261. http://dx.doi.org/10.1002/aqc.620

STEVAUX, JC. and TAKEDA, AM. 2002. Geomorphological processes related to density and variety of zoobenthic community of the upper Paraná River, Brazil. Zeistshrift Für Geomorphologie, vol. 129, p. 143-158.

STRIXINO, G. and TRIVINHO-STRIXINO, S. 1998. Povoamentos de Chironomidae (Diptera) em lagos artificiais. Oecologia Brasilienses - Ecologia de insetos aquáticos, vol. 5, p. 141-154.

STEINMAN, AD., CONKLIN, J., BOHLEN, PJ. and UZARSKI DG. 2003. Influence of cattle grazing and pasture land on macroinvertebrate communities in freshwater wetlands. Wetlands, vol. 23, no. 4, p. 877-889. http://dx.doi.org/10.1672/02775212(2003)023[0877:IOCGAP]2.0.CO;2

TOCKNER, K., PENNETZDORFER, D., REINER, N., SCHIEMER, F. and WARD, JV. 1999. Hydrological connectivity and exchange of organic matter and nutrients in a dynamic river-floodplain system (Danube, Austria). Freshwater Biology, vol. 41, no. 3, p. 521-535. http://dx.doi.org/10.1046/j.13652427.1999.00399.x 
TONDATO, KK., FANTIN-CRUZ, I., PEDROLLO, OC. and SÚAREZ, YR. 2013. Spatial distribution of fish assemblages along environmental gradients in the temporary ponds of northern Pantanal, Brazil. Journal of Limnology, vol. 72, no. 1, p. 95-102. http:// dx.doi.org/10.4081/jlimnol.2013.e8

TRIVINHO-STRIXINO, S. 2011. Larvas de Chironomidae: Guia de identificação. Sáo Carlos: Depto Hidrobiologia/Lab. Entomologia Aquática/ UFSCar. $371 \mathrm{p}$.

TRIVINHO-STRIXINO, S. and STRIXINO, G. 2005. Chironomidae (Diptera) do rio Ribeira (divisa dos estados de São Paulo e Paraná) numa avaliação ambiental faunística. Entomologia y Vectores, vol. 12, no. 2, p. 243-253. http://dx.doi.org/10.1590/S032803812005000200008

TRONSTAD, LM., TRONSTAD, BP. and BENKE, AC. 2005. Invertebrate responses to decreasing water levels in a subtropical river floodplain wetland. Wetlands, vol. 25, no. 3, p. 583-593. http://dx.doi. org/10.1672/0277-5212(2005)025[0583:IRTDW L]2.0.CO;2

WANTZEN, KM., CUNHA, CN., JUNK, WJ., GIRARD, P., ROSSETTO, OC., PENHA, JM., COUTO, EG., BECKER, M., PRIANTE, G., TOMAS WT., SANTOS, WSA., MARTA, J., DOMINGOS, I., SONODA, F., CURVO, M. and CALLIL, C. 2008. Towards a sustainable management concept for ecosystem services of the Pantanal wetland. Ecohydrology and Hydrobiology, vol. 8, no. 2-4, p. 115-138. http://dx.doi.org/10.2478/ v10104-009-0009-9

WIGGINS, GB., MACKAY, RJ. and SMITH, IM. 1980. Evolutionary and ecological strategies of animals in annual temporary pools. Archiv Fur Hydrobiologie Supplement, vol. 58, p. 97-206.

Received: 07 February 2013 Accepted: 14 August 2013 